\title{
Jurist-Diction
}

Volume 3 No. 5, September 2020

\section{Perlindungan Hukum Debitor Pailit Atas Berlarut-Larut Pengurusan dan Pemberesan Harta Pailit Oleh Kurator}

\author{
Ratibulava \\ Ravhaa28@gmail.com \\ Universitas Airlangga
}

\author{
How to cite: \\ Ratibulava, 'Perlindungan \\ Hukum Debitor Pailit Atas \\ Berlarut-Larut Pengurusan Dan \\ Pemberesan Harta Pailit Oleh \\ Kurator' (2020) Vol. 3 No. 5 \\ Jurist-Diction. \\ Histori artikel: \\ Submit 6 Juli 2020; \\ Diterima 14 Agustus 2020; \\ Diterbitkan 1 September 2020. \\ DOI: \\ 10.20473/jd.v3i5.21984
}

\begin{abstract}
Abstrak
Pengaturan terkait dengan proses permohonan pailit telah diatur secara rijid dalam Undang-Undang Kepailitan dan PKPU yang ditunjang oleh adanya SEMA No 2 tahun 2016 tentang Efisiensi dan Transparansi Penanganan Perkara Kepailitan di Pengadilan. Berbeda halnya dengan Pelaksanaan dari adanya Putusan Pailit yakni Proses Pengurusan dan Pemberesan Harta Pailit. UUK dan PKPU memberikan rambu-rambu terkait dengan pelaksanaan dari Proses Pengurusan dan Pemberesan Harta Pailit agar tidak berlangsung secara berlarut-larut. Namun, terdapat regulasi lain diluar Undang-Undang Kepailitan dan PKPU yang secara tersirat mengatur mengenai batasan Proses Pengurusan dan Pemberesan Harta Pailit. Akibat dari adanya Proses Pengurusan dan Pemberesan Harta Pailit oleh Kurator yang berlarut-larut ini, mengakibatkan adanya kerugian bagi stakeholder, terlebih Debitor Pailit. Oleh karena itulah, Kurator harus mempertanggungjawabkan tindakannya tersebut.

Kata Kunci: Kepailitan; Pengurusan dan Pemberesan; Harta Pailit; Berlarut-larut Kurator.
\end{abstract}

\section{Pendahuluan}

Eksistensi Hukum Kepailitan telah ada sejak jaman romawi. Di Indonesia, pengaturan mengenai kepailitan tergolong dalam klasifikasi Hukum Dagang, walaupun tidak serta merta diatur dalam Kitab Undang-Undang Hukum Dagang (KUHD). Peraturan kepailitan ini diatur dalam peraturan tersendiri yaitu dalam “Faillisementsverordering” Staadsblas 1905 No. 2176 jo. Staatsblas 1906 No. 348. ${ }^{1}$

Pada mulanya, terdapat dua macam peraturan mengenai kepailitan yang berlaku di Indonesia sebagai akibat dari pemisahan antara golongan pedagang dan bukan pedagang. Dalam pemberlakuannya, KUHD terbagi menjadi tiga

1 Edward Malik, Cara Mudah Memahami Proses Kepailitan dan Penundaan Kewajiban Utang (CV. Mandar Maju 2012).[9]. 
buku yang mana salah satunya pada Buku Ketiga mengatur Kepailitan dengan judul "Van De Voorsieningen In Geval van Onvermogen van Kooplieden", peraturan mengenai ketidakmampuan pedagang. Pengaturan mengenai hal tersebut terdapat pada Pasal 749 sampai Pasal 910 KUHD, lalu dicabut dengan Pasal 2 "Verordening ter invoering van de Faillisementsverordering" Staadblad Tahun 1960 Np. 348, Pengaturan mengenai Kepailitan yang diperuntukkan bagi pedagang. ${ }^{2}$ Peraturan kepailitan lain yang dapat dijumpai dalam Reglement op de Rechtvordering (RV) Staadblad No. 1847 No. 52 bsd Staatablad Tahun 1849 No. 63, yakni buku ketiga bab ketujuh serta pasal 899 sampai Pasal 915 yang berjudul “Van de Staat van Kennelijk Onvermogen”, peraturan mengenai ketidakmampuan buku Pedagang yang kemudian disebut juga dengan Verordening ter invoering van de Faillisementsverordering. Maka, sebelum tahun 1906 terdapat dua macam peraturan kepailitan yang diberlakukan di Hindia Belanda. ${ }^{3}$

Antara KUHD dan RV terdapat perbedaan yang terletak pada peruntukannya. Pada KUHD berisikan mengenai pengaturan kepailitan untuk pedagang, sedangkan pada RV bukan untuk pedagang. Dalam penerapannya, antara KUHD dan RV memiliki beberapa kelemahan yakni membutuhkan biaya tinggi, terlalu mengedepankan formalitas, minimalnya peran kreditor serta membutuhkan waktu yang berlarut-larut. Aturan kepailitan dalam KUHD dan RV yang dinilai kurang efisien, melahirkan aturan baru yakni Failistment Verordenning yang berlaku berdasar pada Staatblaads No. 217 Tahun 1905 dan Staatsblaad No. 348 Tahun 1906. Keberlakuan Failistment Verordenning berlangsung pada tahun 1905 hingga 1998.

Pada tahun 1997, Indonesia mengalami krisis moneter yang mengakibatkan keberlakuan Failistment Verordenning terhenti. Akibat dari adanya krisis moneter yang menimpa Indonesia menjadikan beberapa perusahaan besar nasional dan multinasional yang berada di Indonesia pailit.

2 Rachmadi Usman, Dimensi Hukum Kepailitan di Indonesia (PT. Gramedia Pustaka Utama 2004).[2]. 
Menanggapi kondisi tersebut, Presiden Indonesia yang menjabat pada saat itu yakni alm. Soeharto menerbitkan Peraturan Pemerintah Pengganti UndangUndang (PERPU) No. 1 Tahun 1998 tentang Perubahan atas Undang-Undang Kepailitan. PERPU No. 1 Tahun 1998 kemudian resmi ditetapkan sebagai UU oleh UU No. 4 tahun $1998 .{ }^{4}$ PERPU No. 1 tahun 1998 mengandung beberapa ketentuan baru yang secara pasti merubah konsep pengaturan kepailitan terlebih dalam hal kurator swasta, pembentukan pengadilan niaga serta batas waktu penyelesaian perkara kepailitan.

Enam tahun berjalan setelah Indonesia mengalami krisis moneter, tepatnya pada tahun 2004 terbit regulasi baru dibidang kepailitan yakni UU No. 37 tahun 2004 tentang Kepailitan dan Penundaan Kewajiban Pembayaran Utang (PKPU). UU Kepailitan dan PKPU memiliki lingkup yang lebih luas jika dibandingkan dengan PERPU No. 1 tahun 1998. Selain itu, UU Kepailitan dan PKPU juga memberikan batasan yang tegas terkait pengertian "utang" dan "jatuh tempo". 5

Keberlakuan UUK dan PKPU ditujukan untuk mengantisipasi beberapa permasalahan yang timbul seperti adanya potensi kecurangan yang dilakukan oleh kreditor maupun debitor, perebutan harta debitor oleh para kreditornya, kreditor separatis menuntut haknya dengan cara serta merta dengan menjual jaminan hak kebendaan setelah adanya putusan pailit, mencegah pengurusan dan pemberesan harta pailit yang terkesan berlarut-larut sehingga merugikan debitor maupun kreditor dan lain sebagainya.

Kepailitan sendiri merupakan serangkaian suatu proses, dimana seorang debitor mempunyai kesulitan keuangan untuk melunasi hutangnya, yang mana ketika telah dinyatakan pailit oleh pengadilan dalam hal ini pengadilan niaga, dikarenakan debitor tersebut tidak dapat membayar utang-utangnya. Dengan demikian harta debitor dapat dibagikan kepada para kreditor, sesuai dengan peraturan pemerintah. ${ }^{6}$

\footnotetext{
4 Bagus Wicaksono, "Sejarah Hukum Kepailitan Indonesia: Warisan Kolonial dan Krismon”, <www.abpadvocates.com,> diakses pada 6 Agustus 2019.

5 ibid.

6 J. Djohansyah, "Pengadilan Niaga, Penyelesaian Utang Melalui Pailit atau Penundaan Kewajiban Pembayaran Utang”, di dalam Rudy Lontoh (Ed) (Alumni Bandung 2003).[23].
} 
Kepailitan merupakan prosedur menghimpun, menginventarisasi dan memaksimalkan aset-aset debitor yang mengalami masalah keuangan, untuk kemudian di distribusikan bagi para kreditor. ${ }^{7}$ Berdasar uraian diatas maka, Kepailitan adalah sita umum yang mencakup seluruh kekayaan debitor untuk kepentingan semua kreditornya, yang merupakan pelaksanaan dari Pasal 1132 KUH Perdata. ${ }^{8}$

Pasal 2 ayat (1) UUK dan PKPU juga menjelaskan mengenai syarat pailit. Selain hal tersebut diatas, dalam UUK dan PKPU juga mengatur mengenai adanya kurator dan pengurus swasta yang bertugas dan berwenang dalam melakukan pengurusan dan pemberesan harta pailit, maupun pengurusan debitor dalam penundaan kewajiban pembayaran utang. Kurator merupakan salah satu pihak yang memiliki peran krusial dalam suatu proses perkara kepailitan. Dalam pasal 69 ayat (1) UUK dan PKPU disebutkan "Tugas Kurator adalah melakukan pengurusan dan pemberesan harta pailit". 9 Persyaratan dan prosedur untuk menjadi Kurator diatur secara ketat dalam UUK dan PKPU. Pasal 70 ayat (1) UUK dan PKPU menyebutkan bahwa yang bertindak sebagai kurator saat ini adalah:

a. BHP (Balai Harta Peninggalan);

b. dan Kurator.

Mengenai jenis Kurator lainnya diatur lebih lanjut dalam Pasal 70 ayat (2), huruf (a) dan (b) yakni perseorangan yang berdomisili di Indonesia, memiliki keahlian khusus yang dibutuhkan dalam rangka mengurus dan atau membereskan harta pailit serta telah terdaftar pada kementerian yang lingkup tugas dan tanggung jawabnya ada dalam bidang hukum dan peraturan perundang-undangan. ${ }^{10}$

Praktiknya, kurator dalam mengurus dan membereskan harta pailit tidaklah mudah, seringkali kurator membutuhkan waktu yang tidak sebentar bahkan hingga berlarut-larut jauh setelah dijatuhkannya putusan pailit.Berlarut-larut

\footnotetext{
7 Kristian Lukas RP Simanjuntak, 'Kedudukan Klausula Arbitrase Dalam Kepailitan Dan Proses Renvooi Kepailitan Terkait Sengketa Nilai Tagihan' (Skripsi, Universitas Gajah Mada 2014).[3].

8 ibid.[2].

9 Pasal 69 ayat (1) UUK dan PKPU.

${ }^{10}$ Pasal 70 ayat (2) UUK dan PKPU.
} 
sendiri merupakan suatu keadaan berlama-lama, berpanjang-panjang tanpa ada penyelesaian. ${ }^{11}$

Sebagai salah satu contoh pengurusan dan pemberesan harta pailit yang berlarut-larut hingga kini adalah Perkara pailit antara Hendrawan Rusli (Pemohon) dan PT Interkon Enterprise (Termohon) yang telah dinyatakan pailit pada sekitar tahun 2006. Namun mengenai pengurusan dan pemberesan harta Termohon pailit hingga kini tahun 2019 masih terus berjalan atau masih belum selesai.

Dalam UUK dan PKPU sebenarnya telah menyatakan secara jelas dan rinci mengenai pengaturan jangka waktu pengurusan harta pailit yang dimulai dari tahap prosedur pengajuan pailit hingga permohonan pernyataan pailit, terlebih pengaturan mengenai masa stay pun juga diatur secara detail, namun mengenai pemberesan harta pailit atau pelaksanaan dari adanya putusan pailit, UUK dan PKPU tidak memberikan pengaturan jangka waktu yang rijid. Pengaturan yang secara rinci dan rijid tersebut juga memberikan rambu-rambu agar segala bentuk pengurusan dan pemberesan harta pailit tidak berlangsung secara berlarut-larut. Faktor lain yang mengakibatkan debitor pailit merasa dirugikan yakni tindakan kurator sebagai pihak yang mengurus dan membereskan harta pailit yang dinilai lalai dan kurang professional dalam menjalankan tugasnya, yang mana kurator secara tersirat menjadi tidak kreatif dalam upaya untuk meningkatkan nilai penjualan harta pailit. Faktor inilah yang dapat menjadikan kurator akan bertanggung jawab secara beban harta pribadinya terpisah dari pembebanan harta pailit. Selain itu, sebagai pihak yang merasa dirugikan dari adanya tindakan kurator yang dinilai lalai dan kurang professional sebagaimana diuraikan diatas, pihak debitor pailit dapat mengajukan upaya hukum sesuai dengan ketentuan yang telah diatur dalam Perundang-undangan yang berlaku sebagai bentuk untuk mendapat perlindungan hukum.

Berdasar pada kasus diatas, maka sangat penting proses penyelesaian pengurusan dan pemberesan harta pailit yang dilakukan oleh kurator secara cepat dan efisien guna melindungi kepentingan debitor pailit. Terlebih jika terdapat hal-hal

${ }^{11} \mathrm{https} / / / \mathrm{kb} b i . w e b . i d /$ larut. 
yang mengakibatkan proses pengurusan dan pemberesan harta pailit berlangsung berlarut-larut maka debitor pailit yang beritikad baik berhak mendapat perlindungan hukum agar ia dapat mendapatkan haknya sebagaimana mestinya.

\section{Akibat Hukum Kepailitan}

Debitor yang berada dalam kondisi berhenti melakukan pembayaran, baik atas laporan pihak kreditor maupun atas permohonannya sendiri, dengan putusan majelis hakim dinyatakan pailit, maka akan melahirkan akibat hukum kepailitan. Menurut Zainal Asikin, akibat hukum dari adanya putusan pailit yang paling utama adalah debitor akan kehilangan hak untuk mengurus dan menguasai seluruh harta kekayaannya yang tergolong kedalam harta pailit. Pasal 69 ayat (1) UUK dan PKPU menyatakan bahwa pengurusan dan penguasaan harta benda tersebut akan beralih ke tangan Kurator atau Balai Harta Peninggalan. Perlu diketahui bahwa dengan adanya putusan pengadilan yang menyatakan debitor pailit, bukan berarti debitor pailit kehilangan hak keperdataannya (volkomen handelingsbevoegdheid) agar dapat melakukan semua perbuatan hukum dibidang keperdataan. ${ }^{12}$

Mengacu pada uraian diatas, terdapat beberapa akibat hukum dari adanya putusan pailit terhadap harta kekayaan debitor maupun terhadap debitor sendiri, antara lain yaitu:

1. Putusan Pailit dapat dijalankan Serta Merta;

2. Sitaan Umum (Public Attachment, Gerechtelijk Beslag);

3. Kehilangan Wewenang dalam Harta Kekayaan;

4. Perikatan Setelah Pailit;

5. Pembayaran Piutang Debitor Pailit;

6. Penetapan Putusan Pengadilan Sebelumnya;

7. Hubungan Kerja dengan Para Pekerja Perusahaan Pailit;

8. Kreditor Separatis dan Penangguhan Hak (Stay);

9. Organ-Organ Perseroan Terbatas;

10. Actio Pauliana dalam Kepailitan;

11. Paksa Badan (Gijzeling);

12. Ketentuan Pidana.

\footnotetext{
12 Sutan Remy Sjahdeini, Hukum Kepailitan (Pustaka Utama Grafiti 2002).[190].
} 


\section{Tugas dan Wewenang Kurator dalam Pengurusan dan Pemberesan Harta Pailit}

Diputuskannya seorang debitor menjadi debitor pailit oleh Pengadilan Niaga membawa konsekuensi hukum, yakni bagi debitor ia akan dijatuhkan sita umum terhadap seluruh harta debitor pailit dan hilangnya kewenangan debitor pailit untuk menguasai dan mengurus harta pailitnya. ${ }^{13}$ Sementara itu, konsekuensi hukum bagi kreditor adalah akan mengalami ketidakpastian mengenai hubungan hukum yang ada antara kreditor dengan debitor pailit. ${ }^{14}$ Maka, untuk kepentingan kedua belah pihak tersebut diatas, UUK dan PKPU menyediakan pihak yang akan mengurus dan membereskan harta pailit serta akan menyelesaikan hubungan hukum yang telah terjalin diantara kedua belah pihak tersebut. Pasal 15 ayat (1) UUK dan PKPU menyatakan bahwa terhadap putusan pernyataan pailit, harus diangkat Kurator dan seorang Hakim Pengawas yang ditunjuk oleh Hakim Pengadilan. ${ }^{15}$ Dengan demikian, terhitung sejak tanggal putusan pailit ditetapkan oleh Pengadilan Niaga, maka Kuratorlah yang berwenang untuk melaksanakan pengurusan dan pemberesan harta pailit walaupun terhadap putusan pailit tersebut masih terdapat upaya hukum lain. Tugas utama Kurator sebagaimana termaktub dalam Pasal 69 ayat (1) UUK dan PKPU adalah Kurator berkewajiban untuk melaksanakan tugas pengurusan dan pemberesan harta pailit.

\section{Batasan Pengaturan Berlarut-larutnya Pengurusan dan Pemberesan Harta Pailit}

UUK dan PKPU berisikan beberapa pasal yang menjelaskan mengenai batasan pengaturan berlarut-larutnya pengurusan dan pemberesan harta pailit, walaupun dalam tiap-tiap pasal tersebut tidak dinyatakan secara tersurat. Keberlakuan pasalpasal yang mengatur mengenai batasan berlarutnya pengurusan dan pemberesan harta pailit ini bertujuan agar dapat memaksimalkan proses pengurusan dan pemberesan harta pailit secara cepat dan efisien sebagaimana prinsip yang dianut

${ }^{13}$ Firmansyah, 'Tanggung Jawab Kurator Dalam Pengurusan Dan Pemberesan Harta Pailit (Studi Kasus Terhadap Apartemen Dan Ruko Palazzo Jakarta)' (Tesis, Magister Ilmu Hukum Universitas Islam Indonesia 2013).[101].

${ }^{14}$ ibid.

15 Pasal 15 ayat (1) UUK dan PKPU. 
dalam Hukum Kepailitan. Berlarut-larut sendiri merupakan suatu keadaan berlamalama, berpanjang-panjang tanpa ada penyelesaian. ${ }^{16}$

\section{Upaya Hukum Debitor Pailit Atas Berlarut-Larut Pengurusan Dan Pemberesan Harta Pailit Oleh Kurator \\ Tanggung Jawab Kurator atas Berlarutnya Pengurusan dan Pemberesan Harta Pailit}

Berdasar pada Prinsipnya, tanggung jawab dibedakan menjadi 2, yakni: Pertama, bertanggung jawab terhadap pelaksanaan pekerjaan dan hasilnya. ${ }^{17}$ Artinya, seseorang wajib bertanggung jawab menjalankan pekerjaannya dengan sebaik mungkin dan menghasilkan hasil yang memuaskan. Kedua, bertanggung jawab atas dampak profesinya terhadap kehidupan dan kepentingan orang lain khususnya kepentingan orang-orang yang dilayaninya. ${ }^{18}$

Kurator memiliki tanggung jawab yang dikatagorikan kedalam salah satu profesi yang berlandaskan prinsip kehati-hatian. ${ }^{19}$ Dalam tahap pengurusan dan pemberesan harta pailit sendiri terdapat 2 (dua) jenis bentuk pertanggung jawaban kurator, yakni pertanggung jawaban kurator dalam kapasitas kurator dan pertanggung jawaban kurator secara pribadi. Pertanggung jawaban kurator dalam kapasitas kurator ini dibebankan pada harta pailit. ${ }^{20}$

\section{Gugatan Perbuatan Melawan Hukum terhadap Kurator}

Kurator sebagai pengurus dan pemberes harta pailit, tentunya memiliki peran krusial dalam kepailitan. Kurator dituntut secara professional, kreatif, independensi dan transparan dalam melakukan pengurusan dan pemberesan harta pailit. Pasal 72 UUK dan PKPU menyatakan bahwa kurator bertanggung jawab terhadap kesalahan

\footnotetext{
${ }^{16}$ https://kbbi.web.id/larut

${ }^{17}$ Lastua Ryanto, 'Tanggung Jawab Kurator Secara Pribadi atas Kesalahan atau Kelalaiannya dalam Pengurusan dan Pemberesan Harta Pailit yang menyebabkan Kerugian' (Skripsi, Universitas Sumatera Utara 2014).[30].

18 ibid.

19 ibid. [30].

${ }^{20}$ Imran Nating, Op. Cit.[116].
} 
atau kelalaiannya dalam melaksanakan tugas pengurusan dan/atau pemberesan yang menyebabkan kerugian terhadap harta pailit. ${ }^{21}$

Dengan demikian, perumusan Pasal 1365 KUH Perdata ini secara limitatif menganut asas hukum bahwa penggantian kerugian dalam hal terjadinya suatu Perbuatan Melawan Hukum bersifat wajib. ${ }^{22}$ Bentuk penggantian kerugian sebagai akibat dari adanya Perbuatan Melawan Hukum yang dilakukan oleh kurator secara teoritis dikatagorikan kedalam 2 (dua) bentuk, yaitu: kerugian yang bersifat aktual. Jika didefinisikan dalam Hukum Perdata, Perbuatan Melawan Hukum memiliki arti yakni suatu perbuatan yang bertentangan dengan hak subjektif seseorang atau bertentangan dengan kewajibannya sendiri menurut Undang-Undang. Sesuai pandangan ini, maka Perbuatan Melawan Hukum adalah perbuatan yang bertentangan dengan Undang-Undang. ${ }^{23}$ Ini menyatakan bahwa perbuatan yang tidak bertentangan dengan undang-undang, namun bertentangan dengan moral atau bertentangan dengan sesuatu yang dianggap tidak patut dalam pergaulan masyarakat bukanlah merupakan Perbuatan Melawan Hukum. ${ }^{24}$

Mencermati ketentuan Pasal 1365 KUH Perdata yang dinyatakan sebagai suatu Perbuatan Melawan Hukum dan dapat dituntut penggantian kerugian apabila telah memenuhi unsur-unsur sebagai berikut: ${ }^{25}$

1. Perbuatan Melawan Hukum;

2. Ada Kesalahan;

3. Terdapat Kerugian;

4. Adanya Hubungan Kausal (sebab-akibat) antara Perbuatan dan Kerugian.

Dalam Hukum Kepailitan, terdapat 2 (dua) subjek hukum kepailitan, yaitu Perseorangan dan Badan Hukum. Kedua subjek hukum ini dapat melakukan gugatan Perbuatan Melawan Hukum terhadap Kurator jika kurator dinilai

${ }^{21}$ Pasal 71 UUK dan PKPU.

${ }^{22}$ Lastua Ryanto, Op. Cit.[56].

${ }^{23}$ Adrian Richikiel Hastika, 'Kewenangan Pengadilan terhadap Gugatan Perbuatan Melawan Hukum yang dilakukan oleh Kurator (Studi Kasus di PLN)', (Tesis, Program Pascasarjana Universitas Airlangga 2018).[29].

${ }^{24}$ ibid.

${ }^{25}$ Moch. Zulkarnain Al Mufti, 'Perlindungan Hukum terhadap Kreditor dan Debitor dalam Pengurusan dan Pemberesan Harta Pailit oleh Kurator' (Tesis, Program Pascasarjana Universitas Islam Indonesia 2016).[72]. 
melakukan kesalahan dan lalai dalam menjalankan tugasnya sehingga merugikan harta pailit sebagaimana dimaksut dalam Pasal 72 UUK dan PKPU. Berlarutnya Pengurusan dan Pemberesan Harta Pailit yang dilakukan oleh Kurator tentunya mengakibatkan kerugian terhadap harta pailit dan debitor pailit yang pada akhirnya menjadikan kondisi debitor pailit tak kunjung normal atau cakap dalam melakukan suatu perbuatan hukum. Oleh karena itu, debitor pailit baik Perseorangan maupun Badan Hukum dapat mengajukan gugatan Perbuatan Melawan Hukum terhadap Kurator terkait dengan berlarutnya pengurusan dan pemberesan harta pailit yang merugikan harta pailit dan debitor pailit. Unsur dalam Pasal 1365 KUH Perdata yang terpenuhi untuk mengajukan gugatan Perbuatan Melawan Hukum terhadap Kurator oleh debitor pailit baik perseorangan dan Badan Hukum terkait dengan berlarutnya pengurusan dan pemberesan harta pailit (studi kasus kepailitan UD. Harapan Kita dan PT. Interkon Kebon Jeruk) adalah:

1. Unsur Perbuatan Melawan Hukum;

2. Adanya Kesalahan;

3. Adanya Kerugian;

4. Terdapat Hubungan Kausal (sebab-akibat) antara Perbuatan dan Kerugian.

Pengajuan gugatan Perbuatan Melawan Hukum oleh subjek hukum kepailitan baik perseorangan maupun badan hukum terhadap kurator yang mengakibatkan keberlarutan pengurusan dan pemberesan harta pailit sebagaimana telah diuraikan diatas, mengacu pada Pasal 3 ayat (1) UUK dan PKPU yang menyatakan bahwa putusan atas permohonan pernyataan pailit dan hal-hal lain yang berkaitan dan/ atau diatur dalam undang-undang ini diputuskan oleh Pengadilan yang daerah hukumnya meliputi daerah tempat kedudukan hukum debitor. ${ }^{26}$ Menurut Hadi Subhan dalam bukunya, beliau berpendapat bahwa yang dimaksut dengan hal-hal lain yakni meliputi actio pauliana, perlawanan pihak ketiga terhadap penyitaan, atau perkara dimana debitor, kreditor, kurator, atau pengurus menjadi salah satu pihak dalam perkara yang berkaitan dengan harta pailit termasuk gugatan kurator terhadap direksi yang menyebabkan perseroan dinyatakan pailit karena kelalaiannya

\footnotetext{
${ }^{26}$ Pasal 3 ayat (1) UUK dan PKPU.
} 
atau kesalahannya.$^{27}$ Dengan demikian, dapat dikatakan bahwa gugatan Perbuatan Melawan Hukum terhadap kurator merupakan suatu gugatan lain-lain yang lahir setelah adanya pernyataan pailit akibat dari tindakan kurator yang dinilai tidak sesuai dengan Pasal 72 UUK dan PKPU dan kurator harus mempertanggung jawabkan tindakannya tersebut.

Kewenangan memeriksa dan mengadili Perbuatan Melawan Hukum terhadap Kurator atas dasar Pasal 1365 KUH Perdata dan disesuaikan dengan tanggung jawab kurator dalam Pasal 72 UUK dan PKPU serta Pasal 3 ayat (1) UUK dan PKPU adalah pada Pengadilan Niaga melalui mekanisme gugatan lainlain. Secara sederhana dapat dinyatakan bahwa gugatan lain-lain ini merupakan perkara-perkara yang timbul sebagai akibat dari ketidakpuasan para pihak setelah adanya pernyataan pailit. Dalam hal inilah Pengadilan Niaga berwenang untuk menyelesaikan seluruh perkara yang dimaksutkan diatas, termasuk dalam kasus berlarutnya pengurusan dan pemberesan harta pailit kurator dapat digugat melakukan Perbuatan Melawan Hukum. ${ }^{28}$

\section{Kajian Kasus Berlarutnya Pengurusan dan Pemberesan Harta Pailit}

Kepailitan Badan Hukum (Dalam Kasus Hendrawan Rusli melawan PT.

\section{Interkon Kebon Jeruk)}

Kasus ini bermula pada tanggal 20 April 1990 Pemohon Hendrawan Rusli secara perseorangan membeli sebidang tanah kavling milik PT. Interkon Kebon Jeruk yang berada di kawasan Taman Kebon Jeruk, Jakarta yang masih masuk dalam sertipikat (induk) Hak Guna Bangunan atas nama PT. Interkon Kebon Jeruk. Hendrawan Rusli selaku pemohon telah melakukan pembayaran secara lunas dan telah melakukan perjanjian pengikatan jual beli (PPJB) dihadapan Notaris tertanggal 31 Mei 1990. Melalui PPJB tersebut, mengisyaratkan bahwa PT. Interkon Kebon Jeruk seharusnya telah menyerahkan sebidang tanah kavling tersebut pada pemohon. Namun, hingga permohonan pailit ini didaftarkan tanggal 23 Mei 2006,

\footnotetext{
${ }^{27}$ M. Hadi Shubhan, Op. Cit.[104].

${ }_{28}$ Adrian Richikiel Hastika, Op.Cit.[32].
} 
PT. Interkon Kebon Jeruk tak kunjung menyerahkan tanah kavling tersebut pada pihak Pemohon. Atas dasar bahwa Termohon memiliki kewajiban penyerahan tanah sebagaimana telah diuraikan diatas serta didukung oleh adanya kreditor lain, maka Pengadilan Niaga Jakarta Pusat menyatakan PT. Interkon Kebon Jeruk pailit dan memutus kasus ini dengan putusan No. 27/Pailit/2006/PN.Niaga.Jkt.Pst tanggal 3 Juli 2006.

Terhadap putusan pailit tersebut, PT. IKJ mengajukan upaya hukum Kasasi dengan dalil bahwa putusan pengadilan niaga dirasa telah keliru. Majelis pada tingkat kasasi yang dipimpin oleh Prof. Effendi Lotulung berpendapat bahwa hubungan yang terjalin antara Hendrawan Rusli (Termohon Kasasi) dengan PT. Interkon Kebon Jeruk (Pemohon Kasasi) merupakan Perjanjian Pengikatan Jual Beli biasa dan tidak mengikat para pihak. Secara sederhana, Majelis pada tingkat Kasasi mendefinisikan utang dari sudut pandang yang sempit sehingga tidak memenuhi unsur-unsur yang terkandung dalam pasal 1 ayat (1) dan pasal 2 ayat (1) UUK dan PKPU. Atas dasar inilah, Majelis Kasasi memutus akan mencabut putusan pailit Pengadilan Niaga dan akan menetapkan Putusan Kasasi MA Nomor 021/K/N/2006 tanggal 8 September 2006.

Pihak Hendrawan Rusli (Termohon Kasasi) mengajukan Peninjauan Kembali terhadap putusan majelis Kasasi. Majelis PK yang terdiri dari Prof. Bagir Manan, Gunanto Suryono dan Prof Muchsin menyatakan bahwa Majelis pada tingkat Kasasi telah melakukan kesalahan berat dalam penerapan hukum tentang utang sebagaimana dimaksutkan dalam Pasal 1 ayat (1) UUK dan PKPU. Selain itu, Kuasa Hukum Hendrawan Rusli menguatkan dalilnya bahwa PT. Interkon Kebon Jeruk dapat untuk dipailitkan karena memang telah memenuhi unsur-unsur pailit sebagaimana diatur dalam Pasal 2 ayat (1) UUK dan PKPU dengan membawa neraca keuangan PT. Interkon Kebon Jeruk sejak bulan Maret, April, Mei 2006. ${ }^{29}$ Yang mana melalui neraca keuangan PT. Interkon Kebon Jeruk tersebut terkuak bahwa PT. Interkon Kebon Jeruk telah memiliki sejumlah utang baik utang dalam

\footnotetext{
29 “Akhirnya Interkon Kebon Jeruk Dinyatakan Pailit”, (16 April 2007) <www. hukumonline.com>, diakses pada 22 oktober 2019.
} 
jangka waktu panjang maupun pendek, seperti misalnya utang pada kantor pajak sebesar Rp 5,2 Milyar dan kantor PBB sebesar Rp 14,96 Milyar. ${ }^{30}$ Dengan adanya utang ini, semakin menguatkan dalil Hendrawan Rusli yang menyatakan bahwa PT. Interkon Kebon Jeruk memiliki utang yang pada intinya utang PT. Interkon Kebon Jeruk lebih besar daripada modal dan memiliki lebih dari 2 (dua) kreditur. Maka, dengan berdasar pada dalil dan bukti-bukti yang telah diberikan oleh Kuasa Hukum Hendrawan Rusli (Pemohon PK) majelis pada tingkat PK memutuskan dalam Putusan Nomor 019/PK/N/2006 tertanggal 21 Februari 2006 bahwa Termohon PK PT. Interkon Kebon Jeruk pailit dengan segala akibat hukumnya.

Jadi, setelah Pengadilan Niaga Jakarta Pusat memutus PT. Interkon Kebon Jeruk pailit dengan nomor register perkara tersebut diatas, Kurator dapat langsung melaksanakan tugas dan fungsinya yang dimulai dari tahap pengumuman pernyataan pailit, dimana kurator akanmembuat daftar pencatatan harta pailit dalam jangka waktu maksimal 2 (dua) hari setelah kurator menerima surat pengangkatannya. Pencatatan harta pailit yang dilakukan oleh kurator terhadap PT. Interkon Kebon Jeruk ini tentunya untuk mengetahui jumlah harta atau asset yang dimiliki oleh PT. Interkon Kebon Jeruk yang nantinya akan didistribusikan kepada para kreditornya. Tahap selanjutnya, yakni kurator atas seijin Hakim pengawas akan melaksankan Rapat Kreditor Pertama, maksimal 30 (tiga puluh) hari setelah putusan pailit ditetapkan. Kurator pada kasus PT IKJ ini diwakili oleh Yan Apul Ruma \& Partners yang mana mereka atas seijin Hakim Pengawas telah menetapkan Rapat Kreditor Pertama yang akan berlangsung pada 20 Juli 2006. Pada tahap Rapat Kreditor Pertama kasus Hendrawan Rusli melawan PT. IKJ ini, telah dihadiri oleh 42 (empat puluh dua) kreditor yang mana mereka juga berperan sebagai kuasa dari 75 (tujuh puluh lima) kreditor lainnya. ${ }^{31}$ Kegelisahan para kreditur ini semakin meningkat ketika pada Rapat Kreditur Pertama tersebut, Direktur Utama PT. Interkon Kebon Jeruk yakni Mashud Wisnu Sarjono tidak dapat hadir, yang hadir hanyalah Wakil

\footnotetext{
${ }^{30}$ ibid.

31 “Tak Hadiri Rapat Kreditor, Debitur diancam Gijzeling”, (Jumat 21 Juli 2006) <www. hukumonline.com>, diakses pada 22 oktober 2019.
} 
Direktur Utama PT IKJ yakni Edy Yuwono. ${ }^{32}$ Ketidakhadiran Direktur Utama PT IKJ ini membuat Hakim Pengawas yakni Binsar Siregar kesal. Ia menganggap bahwa ketidakhadiran Direktur Utama PT IKJ merupakan suatu tindakan ketidak kooperatifan dari debitur pailit. Oleh karena itu, Binsar Siregar akan memberikan sanksi tegas pada Direktur Utama PT IKJ jika ia kembali mangkir pada Rapat Pencocokan Piutang yang akan digelar pada 9 Agustus 2006. Kurator Yan Apul \& Partners juga telah menetapkan batas akhir pengajuan tagihanpara kreditur harus diserahkan maksimal 4 Agustus 2006, tepat 5 (lima) hari sebelum Rapat Pencocokan Piutang dilaksakan.

Pada Rapat Pencocokan Piutang yang terlaksana tanggal 9 Agustus 2006, Yan Apun \& Partners sebagai kurator yang ditunjuk dalam putusan pailit ini menyatakan bahwa sudah terdapat 191 kreditor yang telah mendaftarkan tagihannya. Dalam Rapat Pencocokan Piutang inipun, dihadiri oleh Mashud Wisnu selaku Direktur Utama PT IKJ yang mana iamenyatakan bahwa managemen perusahaan sebenarnya berkeinginan untuk memenuhi hak-hak kreditornya. ${ }^{33}$ Selain itu, PT IKJakan melindungi dan menghormati para konsumen serta tidak ada niatan untuk merugikan para konsumennya. ${ }^{34}$ Oleh karena pernyataannya tersebut, Binsar Siregar selaku Hakim Pengawas mengajukan pertanyaan pada Direktur Utama PT IKJ berupa apakah benar bahwa PT IKJ tidak perlu dipailitkan karena perusahaan tersebut masih mampu untuk membayar utang pada para kreditornya?. Mashudpun menjawab dengan lantang bahwa PT IKJ mampu untuk membayar utang pada para kreditornya. Setelah melalui proses yang panjang disertai dengan pernyataan kesanggupan dari Direktur Utama PT IKJ untuk melunasi segala utangnya pada para kreditor termasuk utangnya pada Hendrawan Rusli, PT IKJ kemudian mengajukan upaya perdamaian dan hal tersebut telah disetujui oleh para kreditor dan Hakim Pengawas.

\footnotetext{
32 ibid.

33 "Setelah dinyatakan Pailit, Dirut Interkon Mengaku Sanggup Bayar Utang", (10 Agustus 2006), <www. hukumonline.com>, diakses pada 22 oktober 2019.

34 ibid.
} 
Proses perdamaian ini berlangsung cukup lama hingga pada tahun 2010 hakim menetapkan permohonan pembatalan perdamaian PT IKJ dengan Nomor 03/ PembatalanPerdamaian/2010/PN.Niaga.Jkt.Pst. Pembatalan perdamaian PT IKJ ini, dipicu oleh adanya wanprestasi yang dilakukan oleh PT IKJ terhadap para kreditornya terkait dengan tidak sesuainya prestasi yang diberikan oleh PT IKJ, yang mana hal tersebut bertentangan dengan apa yang telah diperjanjikan dalam perjanjian perdamaian. Hingga saat ini, memasuki taun ke 13 kasus pailitnya PT IKJ tak kunjung berakhir dan semakin berlarut-larut. Hal ini dibuktikan dengan adanya pengumuman bagi para kreditor yang belum mendaftarkan tagihannya (berkas terlampir). Pengumuman bagi para kreditor ini bersifat insidentiil karena banyaknya kreditor yang diketahui namun mereka tak kunjung mendaftarkan tagihannya. Hal ini tentunya akan menghambat proses pengurusan dan pemberesan harta pailit yang cepat dan efisien.

Bukti lain yang menyatakan bahwa kasus PT IKJ masih berproses hingga saat ini adalah dengan adanya gugatan-gugatan dari pihak lain diluar kasus antara Hendrawan Rusli dan PT IKJ yang merasa tanahnya disangkut pautkan dengan asset PT IKJ hanya karena tanah milik Achmad Syamsudin masuk kedalam area perumahan Taman Kebon Jeruk. Perkara ini didaftarkan di Pengadilan Negeri Jakarta Barat dengan Nomor Register Perkara 268/Pdt.G/2017/PN.Jkt.Brt. Hal ini menjadikan kurator sesuai dalam Pasal 36 UUK dan PKPU harus sesegera mungkin meneruskan atau menghentikan kasus tersebut agar tidak berlarut-larut dan mempengaruhi proses pengurusan dan pemberesan harta pailit.

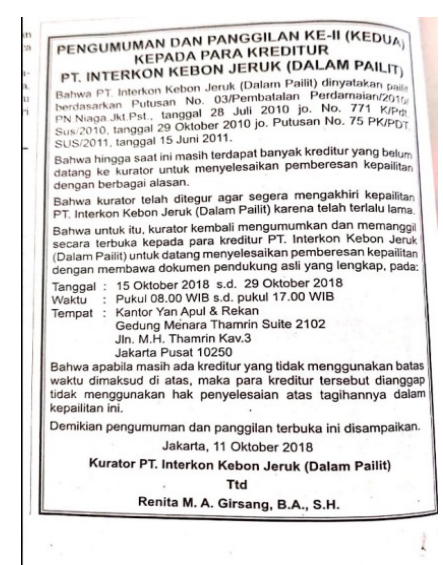

Sumber: Koran Harian Republik Indonesia (SINDO) 


\section{Kepailitan Perseorangan (Dalam Kasus UD. Harapan Kita)}

Jonathan Wisnu Wardhana merupakan Pemohon Pailit yang mengajukan pailit terhadap UD. Harapan Kita. Pemohon merupakan pemilik atau penanggung jawab atau Direktur dari UD. Harapan Kita yang kegiatan usahanya meliputi perdagangan barang yang beralamat di Jl. Camelia gang 1 no. 14 Perumahan Garden Dian Regency, Sidoarjo. UD. Harapan Kita memiliki Kantor Perusahaan yang berada pada Komplek Pergudangan Mutiara Margomulyo Indah blok J nomor 20. Secara sederhana, Pemohon Pailit mengajukan Permohonan Pailit terhadap dirinya sendiri yang dipicu karena Pemohon tidak dapat membayar utang yang telah jatuh tempo pada 2 (dua) kreditornya yakni, CV. Sumber Karunia Abadi sebesar Rp. 10.000.000 dan CV. Purnama Raya sebesar RP. 15.000.000, sehingga total tunggakan utang Pemohon yang telah jatuh tempo sebesar Rp. 25.000.000. Utang Pemohon yang telah jatuh tempo pada para kreditornya ini diperkuat dengan adanya bukti faktur penjualan oleh para kreditor sejak bulan Januari hingga Mei dan Juni tahun 2011. Pemohon pailit menyatakan bahwa dirinya tidak sanggup membayar sejumlah utangnya dikarenakan kondisi kas perusahaan yang terus menerus merugi.

Diketahui bahwa Usaha Dagang merupakan perusahaan perseorangan yang dilakukan atau dijalankan oleh satu orang pengusaha. ${ }^{35}$ Modal dalam perusahaan perseorangan juga dimiliki oleh satu orang dan pengusahanya bertindak langsung dalam pengelolaan perusahaan, walaupun kadang membutuhkan bantuan dari beberapa pekerja. Pekerja ini berperan sebagai pembantu pengusaha dalam pengelolaan perusahaan berdasar pada pemberian kuasa atau pemberian kerja, bukan sebagai pengelola. Dalam perusahaan perseorangan tidak terdapat pemisahan kekayaan antara kekayaan pribadi pemilik dengan kekayaan perusahaan. Dengan demikian, dapat dikatakan bahwa seluruh harta kekayaan pemilik menjadi jaminanbagi semua utang perusahaannya. Hal ini menjadikan perusahaan perseorangan memiliki tanggung jawab yang tidak terbatas.

\footnotetext{
${ }^{35}$ Sentosa Sembiring, Hukum Dagang (PT. Citra Aditya Bakti 2001).[18].
} 
Atas uraian hal-hal diatas, hakim majelis Sriyatmo Joko Sungkowo S.H (ketua majelis), Suko Triyono S.H M.H dan Siti Jamzanah S.H M.H (anggota majelis) memutus perkara ini dengan Nomor Register 12/Pailit/2012/PN-Niaga. Sby pada tanggal 8 Juni 2012. Majelis juga mengangkat Sdr. Suko Triyono S.H M.H sebagai Hakim Pengawas dan Balai Harta Peninggalan sebagai Kurator. Balai Harta Peninggalan sebagai Kurator dalam Kasus ini mengawali tugasnya dengan melakukan Pengumuman pada Berita Negara dan Surat Kabar Harian 7 (tujuh) hari setelah adanya putusan pailit tersebut yakni tanggal 15 Juni 2012. Dalam Pengumuman pailit yang dilakukan oleh Balai Harta Peninggalan berdasar penetapan Hakim Pengawas, akan mengadakan Rapat Kreditor Pertama pada 27 Juni 2012. Rapat Kreditor Pertama ini dihadiri oleh Direktur dari para Kreditor yakni CV. Sumber Karunia Abadi dan CV. Purnama Raya sebagai pihak yang menginginkan pembayaran utang terlaksana dengan segera mungkin. Para pihak dalam Rapat Kreditor Pertama bersepakat untuk melakukan Rapat Kreditor Kedua karena dirasa perlu dan terlaksana pada 5 Juli 2012.

Setelah berlangsungnya Rapat Kreditor Pertama dan Kedua sebagaimana telah diuraikan diatas, Kurator kemudian menggelar Rapat verififkasi atau Rapat Pencocokan Piutang pada 25 Juli 2012. Rapat Pencocokan Piutang ini digelar untuk mencocokkan segala utang-utang debitor pailit guna mengetahui seberapa besar piutang yang dapat dibayarkan pada para kreditornya yakni CV. Sumber Karunia Abadi dan CV. Purnama Raya. Pada tahap ini, juga menetapkan bahwa tagihan utang debitor pailit terhadap CV. Sumber Karunia Abadi sebesar Rp. 10.000.000 dan CV. Purnama Raya sebesar Rp. 15.000.000.

Debitor pailit dalam Rapat Kreditor Pertama, Kedua hingga Pencocokan Piutang sama sekali tidak pernah hadir walaupun telah dipanggil dan diumumkan secara patut. Dengan demikian UUK dan PKPU mengisyaratkan bahwa tidak dapat ditawarkan upaya Perdamaian dalam kasus Pailit ini. Oleh karena itu, Hakim Pengawas Suko Triyono S.H M.H menetapkan UD. Harapan Kita (dalam pailit), berada dalam keadaan Insolvensi pada tanggal 25 Juli 2012. Sejak pernyataan Insolvensi tersebut, hingga kini tahun 2019 kasus pailit UD. Harapan Kita belum 
terselesaikan. Alasan yang mendasari kasus ini tak kunjung terselesaikan hingga memakan waktu 7 tahun yakni para Kreditor tak kunjung mengambil haknya sebagaimana yang telah ditetapkan oleh Kurator. Ini juga dipicu karena jumlah yang didapatkan para Kreditor tidak sesuai dengan harapan mereka atau tidak sesuai dengan jumlah tagihan yang diakui.

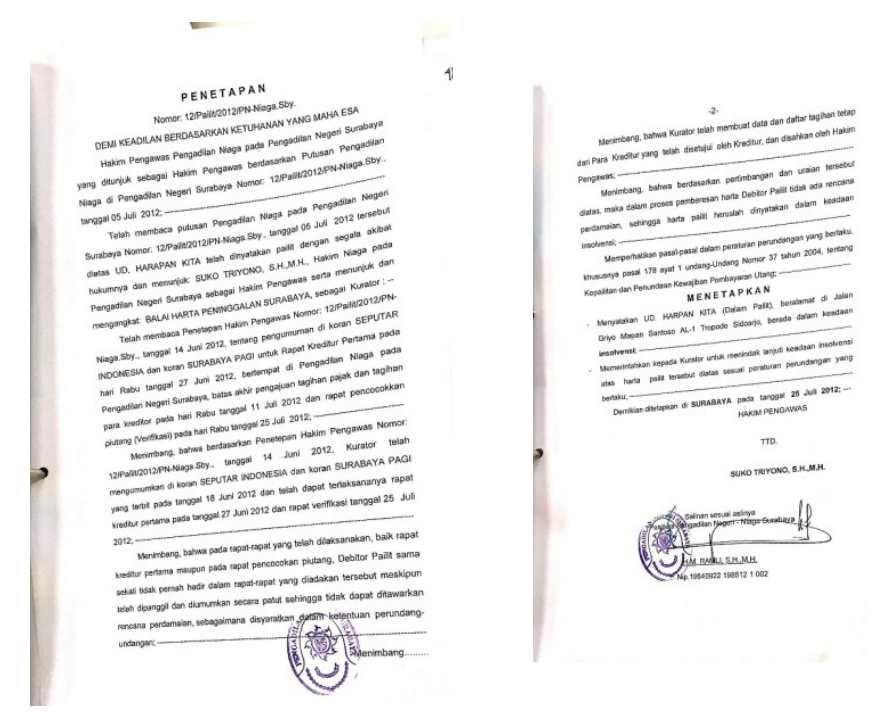

Sumber: Penetapan No. 12/Pailit/2012/PN-Niaga.Sby.

Berdasar pada kedua kasus berlarut-larutnya pengurusan dan pemberesan harta pailit diatas, tentunya sangat merugikan pihak debitor pailit. Yang mana akhirnya pihak Debitor pailit tak kunjung mendapat kepastian hukum dan akan terus berada pada kondisi pailit atau posisi yang tidak sehat. Dalam taraf ini, profesionalitas dan kreatifitas Kurator harus dibuktikan. Kurator dituntut untuk memiliki beragam cara dan upaya agar dapat mencegah terjadinya kerugian terhadap debitor pailit. Salah satu bentuk professionalitas dan kreatifitas kurator ini ditunjukkan dengan penguasaan kasus pailit yang sedang ditangani dengan baik disertai dengan mengetahui situasi dan kondisi pasar mengenai kapan harga penjualan meningkat dan menurun sebagai bentuk pencegahan berlarutnya pengurusan dan pemberesan harta pailit. Jika hal ini berlangsung berlarut-larut maka kurator dianggap kurang professional, kreatif dan lalai dalam menjalankan tugasnya. Tentunya, kerugian atas berlarut-larutnya pengurusan dan pemberesan harta pailit ini dapat diakhiri, pengakhiran kepailitan menjadikan perusahaan dapat beroperasi kembali seperti 
sedia kala. Terlebih, setelah adanya pengakhiran kepailitan, pihak debitor pailit dapat mengajukan Upaya Rehabilitasi sebagaimana terdapat dalam Pasal 215 UUK dan PKPU. Dalam pasal tersebut disebutkan bahwa pihak debitor pailit dapat mengajukan Upaya Rehabilitasi kepada Pengadilan yang memutus pernyataan pailit. Upaya Rehabilitasi ini sangat penting guna menjamin kepastian hukum debitor pailit agar dapat membangun usaha yang baru maupun meneruskan pengoperasian usahanya kembali. Selain itu, Upaya Rehabilitasi ini juga penting guna mengembalikan citra atau nama baik debitor pailit atau reputasi debitor pailit agar dapat mendapat kepercayaan dari kreditor-kreditornya kembali sehingga kedudukan debitor menjadi lebih pasti. Berkenaan dengan berlarutnya pengurusan dan pemberesan harta pailit yang dijalankan oleh kurator ini, maka pihak debitor pailit selaku pihak yang dirugikan dapat menuntut adanya pertanggung jawaban dari pihak Kurator.

\section{Kesimpulan}

Pengaturan mengenai jangka waktu Pengurusan dan Pemberesan harta pailit secara normatif tidak diatur dalam UUK dan PKPU. Namun, tiap-tiap Pasal dalam UUK dan PKPU secara tersirat mengisyaratkan bahwa proses Pengurusan dan Pemberesan harta pailit harus berjalan secara cepat dan efisien seperti halnya Asas yang dianut dalam Hukum Kepailitan.

Berlarutnya Pengurusan dan Pemberesan Harta Pailit oleh Kurator tentunya sangat merugikan Debitor Pailit, yang mana atas tindakannya tersebut Debitor Pailit tak kunjung dapat kembali normal atau kembali cakap untuk melakukan suatu Perbuatan Hukum.

\section{Daftar Bacaan}

\section{Buku}

Edward Malik, Cara Mudah Memahami Proses Kepailitan dan Penundaan Kewajiban Utang (CV. Mandar Maju 2012).

J. Djohansyah, Pengadilan Niaga, Penyelesaian Utang Melalui Pailit atau 
Penundaan Kewajiban Pembayaran Utang, di dalam Rudy Lontoh (Ed) (Alumni Bandung 2003).[23].

Rachmadi Usman, Dimensi Hukum Kepailitan di Indonesia (PT. Gramedia Pustaka Utama 2004).

Sentosa Sembiring, Hukum Dagang (PT. Citra Aditya Bakti 2001).

Sutan Remy Sjahdeini, Hukum Kepailitan (Pustaka Utama Grafiti 2002).

\section{Karya Ilmiah}

Adrian Richikiel Hastika, 'Kewenangan Pengadilan terhadap Gugatan Perbuatan Melawan Hukum yang dilakukan oleh Kurator (Studi Kasus di PLN)', (Tesis, Program Pascasarjana Universitas Airlangga 2018).

Firmansyah, 'Tanggung Jawab Kurator Dalam Pengurusan Dan Pemberesan Harta Pailit (Studi Kasus Terhadap Apartemen Dan Ruko Palazzo Jakarta)' (Tesis, Magister Ilmu Hukum Universitas Islam Indonesia 2013).

Kristian Lukas RP Simanjuntak, 'Kedudukan Klausula Arbitrase Dalam Kepailitan Dan Proses Renvooi Kepailitan Terkait Sengketa Nilai Tagihan' (Skripsi, Universitas Gajah Mada 2014).

Lastua Ryanto, 'Tanggung Jawab Kurator Secara Pribadi atas Kesalahan atau Kelalaiannya dalam Pengurusan dan Pemberesan Harta Pailit yang menyebabkan Kerugian' (Skripsi, Universitas Sumatera Utara 2014).

Moch. Zulkarnain Al Mufti, 'Perlindungan Hukum terhadap Kreditor dan Debitor dalam Pengurusan dan Pemberesan Harta Pailit oleh Kurator' (Tesis, Program Pascasarjana Universitas Islam Indonesia 2016).

\section{Laman}

“Akhirnya Interkon Kebon Jeruk Dinyatakan Pailit”, (16 April 2007) $<w w w . \quad$ hukumonline.com>, diakses pada 22 oktober 2019.

Bagus Wicaksono, "Sejarah Hukum Kepailitan Indonesia: Warisan Kolonial dan Krismon”, <www.abpadvocates.com,> diakses pada 6 Agustus 2019.

"Setelah dinyatakan Pailit, Dirut Interkon Mengaku Sanggup Bayar Utang”, (10 Agustus 2006), <www. hukumonline.com>, diakses pada 22 oktober 2019.

"Tak Hadiri Rapat Kreditor, Debitur diancam Gijzeling", (Jumat 21 Juli 2006) $<w w w$. hukumonline.com>, diakses pada 22 oktober 2019. 


\section{Perundang-undangan}

Burgerlijk Wetboek atau disebut juga Kitab Undang-Undang Hukum Perdata selanjutnya disebut KUHPer.

Undang-Undang Nomor 4 Tahun 1998 tentang Penetapan Peraturan Pemerintah Pengganti Undang-Undang Nomor 1 tahun 1998 tentang Perubahan Atas Undang-Undang tentang Kepailitan menjadi Undang-Undang.

Undang-Undang Nomor 37 tahun 2004 tentang Kepailitan dan Penundaan Kewajiban Pembayaran Utang selanjutnya disebut UUK dan PKPU.

\section{Putusan Pengadilan}

Putusan Nomor 27/Pailit/2006/PN.Niaga.Jkt.Pst.

Putusan Kasasi Mahkamah Agung Nomor 021/K/N/2006.

Putusan Peninjauan Kembali Nomor 019 PK/N/2006.

Putusan Nomor 12/Pailit/2012/PN-Niaga.Sby. 
1904 Ratibulava: Perlindungan Hukum Debitor

--halaman ini sengaja dibiarkan kosong-- 